\title{
INFLUENCE OF PARTIAL FAT REPLACEMENT WITH LECITHIN ON THE PRODUCT CHARACTERISTICS OF A SPECIAL HUNGARIAN COLD CUT
}

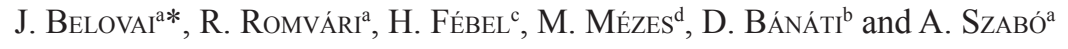 \\ ${ }^{a}$ Faculty of Animal Science, Kaposvár University, H-7400 Kaposvár. Guba Sándor u. 40. Hungary \\ ${ }^{\mathrm{b}}$ Central Food Research Institute, H-1022 Budapest, Herman Ottó út 15. Hungary \\ ${ }^{\mathrm{c}}$ Research Institute of Animal Breeding and Nutrition, H-2053 Herceghalom, Gesztenyés u. 1. Hungary \\ ${ }^{\mathrm{d}}$ Szent István University, H-2100 Gödöllő, Páter Károly utca 1. Hungary
}

(Received: 9 April 2015; accepted: 8 July 2015)

\begin{abstract}
Replacement of animal fat with plant oils is a very popular research field, due to the increasing prevalence of cardiovascular diseases in association with saturated fatty acid consumption. The aim of this study was to reduce amount of pig backfat in a meat product (Párizsi) and to partially replace it with soybean- (SBL) or sunflower lecithin (SFL). Between the samples difference was realized in fatty acid (FA) profile, mostly in total n6 FA content. The replacement also altered the colour compared to the control. The oxidative stability (MDA) analysis showed that SBL was more prone towards preparation technology (10 nmol MDA/g) than the SFL (9 nmol MDA/g). The lecithin appeared as foreign taste based on the sensory test. The aromatic difference, as assessed with electronic nose, was clearly detectable between SFL and SBL. The increasing supplementation levels were also properly distinguished with discriminant analysis within the SBL and SFL series. Summarized, SFL was found to be a better antioxidant, but SBL improved the FA profile into a more favourable state. The lecithin-replacement made unlikeness in the taste compared to the control.
\end{abstract}

Keywords: meat product, unsaturated fatty acids, soybean lecithin, sunflower lecithin, electronic nose

Meat is one of the most important components of the diet as a fat and fatty acid resource in developed countries (TokUSOGLu \& ÜNAL, 2002). Nowadays, many experiments aim at fatreduction in meat products or making the fatty acid profile more favourable, reducing the amount of saturated fatty acid (SFA), and increasing the mono- and unsaturated fatty acid content. The fact, that the fat content has an effect on various physicochemical and sensory characteristics, as flavour, mouth-feel, juiciness, texture, handling, bite, heat transfer, etc., (PeArson \& Gillett, 1999) render this work more difficult.

Glycerophospholipids (GPLs) extracted from food products are defined as "dietary GPLs". The vegetable oilseeds, such as soybeans, rapeseed, and sunflower seed, are commercial lecithin sources, and in the plant raw materials the phospholipid (PL) concentration is usually between $0.3-2.5 \%$ (SCHNEIDER \& VIRMANI, 2001). Soybean GPLs are characterized by high content of essential unsaturated FAs (linoleic acid, C18:2 n6) (KüLlEnBERG et al., 2012). The egg yolk, milk and brain tissue, as animal sources provide substantially higher PL concentrations, ranging from 2\% to 14\% (OKE et al., 2010). In a normal diet, the daily intake of phosphocholine, which is an intermediate in the synthesis of phosphatidylcholine in tissues, is approximately $2-8 \mathrm{~g}$ per day (CoHN et al., 2010).

\footnotetext{
* To whom correspondence should be addressed.

Phone: +36-30-4777943; e-mail: judit.belovai@gmail.com
} 
In the food industry lecithin is used as an emulsifier, lubricant, antioxidant, viscosity reducer, and as an anti-spattering, wetting, and release agent (Rossi, 2007). Small amounts of lecithin are enough in foods ( $0.1-2 \%)$, and at these low levels of usage, the colour, odour, and flavour of lecithin are not marked. It has a "generally recognized as safe" (GRAS) status in foods with no limitation other than current good manufacturing process (SCHNEIDER \& VIRMANI, 2001).

The aim of this study was to replace the back fat in a special, Hungarian cold cut (Párizsi) directly with different vegetable lecithins and to determine the consequent changes of product quality characteristics.

\section{Materials and methods}

The samples were prepared according to BelovaI and co-workers (2014) (Table 1). The vegetable lecithin sources were commercially available sunflower (SFL) and soybean (SBL) lecithin liquid (Cargill Ltd., Hungary). The level of lecithin was chosen on the basis of a preliminary experiment and sample numbering was kept. Before the measurements, the samples (250 g Párizsi/sample) were stored in a refrigerator for $24 \mathrm{~h}$.

Table 1. Ingredients of the samples with graded lecithin substitutions of the backfat

\begin{tabular}{lccccccl}
\hline $\begin{array}{l}\text { Pork meat } \\
(\mathrm{g})\end{array}$ & $\begin{array}{c}\text { Backfat } \\
(\mathrm{g})\end{array}$ & Ice $(\mathrm{g})$ & $\begin{array}{c}\text { Soybean } \\
\text { lecithin } \\
(\mathrm{g})\end{array}$ & $\begin{array}{c}\text { Sunflower } \\
\text { lecithin } \\
(\mathrm{g})\end{array}$ & $\begin{array}{c}\text { Spice } \\
\text { mix }(\mathrm{g})\end{array}$ & $\begin{array}{c}\text { Nitrite } \\
\text { pickling } \\
\text { salt }(\mathrm{g})\end{array}$ & Enrichment \\
\hline 1350 & 1200 & 450 & 0 & 0 & 30 & 60 & Control \\
1350 & 1182 & 450 & 18 & - & 30 & 60 & $1.5 \%$ Soybean lecithin \\
1350 & 1164 & 450 & 36 & - & 30 & 60 & $3 \%$ Soybean lecithin \\
1350 & 1128 & 450 & 72 & - & 30 & 60 & $6 \%$ Soybean lecithin \\
1350 & 1200 & 450 & 0 & 0 & 30 & 60 & Control \\
1350 & 1182 & 450 & - & 18 & 30 & 60 & $1.5 \%$ Sunflower lecithin \\
1350 & 1164 & 450 & - & 36 & 30 & 60 & $3 \%$ Sunflower lecithin \\
1350 & 1128 & 450 & - & 72 & 30 & 60 & $6 \%$ Sunflower lecithin \\
\hline
\end{tabular}

For the determination of fatty acid composition, the samples were ground with grinder (Braun K3000, Germany). From the minced sample $\sim 300 \mathrm{mg}$ were homogenized in a 20 -fold volume of chloroform-methanol $(2: 1 \mathrm{v} / \mathrm{v})$ and total lipid content was extracted according to FolCH and co-workers (1957). Solvents were ultrapure-grade (Sigma-Aldrich, Schnelldorf, Germany) and $0.01 \%(\mathrm{w} / \mathrm{v})$ butylated hydroxytoluene was used as antioxidant. Lipids were transmethylated with the acid-catalysed methanolic $\mathrm{H}_{2} \mathrm{SO}_{4}$ method of CHRISTIE and HAN (2010). Nonadecaenoic acid was used as an internal standard. Gas liquid chromatography was performed on a Shimadzu 2010 apparatus, equipped with a SP-2380 (Supelco, Bellefonte, USA) type capillary column $(30 \mathrm{~m} \times 0.25 \mathrm{~mm}$ internal diameter, $0.20 \mu \mathrm{m}$ film $)$ and flame ionisation detector (FID $2 \times 10^{-11}$ ).

The colour measurement of Párizsi surface was obtained using a tristimulus colorimeter (Minolta Chroma Meter CR-300, Minolta Corporation, Tokyo, Japan). The b* (yellowness), 
$\mathrm{a}^{*}$ (redness), and L* (lightness) values were measured three times on surface of the Párizsi. In each case the measurement was repeated 5 times/sample.

The extent of lipid peroxidation was characterized with the photometric determination of malondialdehyde. The estimation of thiobarbituric reactive substances' (TBARS) levels was performed by the method of PLACER and co-workers (1966).

The organoleptic analysis was performed by 10 skilled evaluators with only fresh samples, at the Central Food Research Institute (CFRI, Budapest, Hungary). Product characteristics were marked on a $0-100$ unstructured scale and the following traits were enrolled in the analysis: colour intensity, odour, spice odour, chewing resistance, chewing moisture, chewing fattiness, saltiness, taste of the meat dollop, spice intensity, foreign odour or taste, and overall preference.

An $\alpha$ Fox 4000 (Alpha Mos, Toulouse, France) type Electronic Nose (EN) with a 18 metal oxide sensor array (MOS) was used. The adsorption of volatile compounds onto the MOS surface generates a change in the electrical resistance of the sensors, which varies with the type of compound and its concentration in the headspace (HS). According to the applied static HS technique, samples were placed in hermetically sealed $20 \mathrm{ml}$ vials. After the equilibrium has been established between the matrix and gaseous phase, an Alpha Mos HS 100 auto sampler was used for sampling the HS. Synthetic air was used as a carrier gas. The acquisition time and time between subsequent analyses were 120 and $1080 \mathrm{~s}$, respectively. From each sample ten repetitions were performed ( 2 lecithin types $\times 4$ different concentration $\times 10$ times, $\mathrm{n}=80$ ). All vials contained $\sim 1 \mathrm{~g}$ samples. During the $\mathrm{EN}$ method development, the use of the following parameters provided acceptable signal intensity values: sample temperature $80^{\circ} \mathrm{C}$, equilibration time $180 \mathrm{~s}$ with agitation, injection volume $3000 \mu \mathrm{l}$, injection

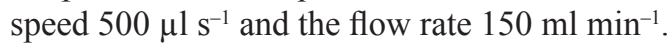

One-way analysis of variance was used for all fatty acid data, with Tukey's post hoc test, using IBM SPSS 20 for Windows (2009) software. The sensory test results were analysed with PanelCheck V1.4.0 software. The raw EN sensor values were saved in the form of relative resistance changes $\left(\Delta R / R_{0}\right)$. The classification of meat samples was done by MGLH (Multivariate General Linear Hypothesis) stepwise procedure and discriminant analysis (DA) and results were tested by cross-validation (CV). Percentage of correctly classified samples were presented (CV\%) as indicator of accuracy of the method.

\section{Results and discussion}

The plant lecithin is a good source of PUFA, but especially n6 essential FAs. The SBL has however a lower $\mathrm{n} 6 / \mathrm{n} 3$ ratio (9.65) as compared to pork (14.33) and backfat (12.74), thus a mild $\mathrm{n} 3 \mathrm{FA}$ enrichment was expected from this constituent. In contrast, SFL contains a very high amount of n6 FAs $(67.3 \%$, w/w), leading to a least favourable $\mathrm{n} 6 / \mathrm{n} 3$ ratio, but a marked increase in unsaturation. Table 2 shows the weight proportional (w/w \% of FA) FA profile obtained from the graded lecithin substitutions of the products. The gradual SBL substitution decreased the proportion of palmitic acid and gondoic acid and increased linoleic acid proportion. The substitution successfully decreased the level of saturation and monounsaturation (MUFA), increased the PUFA (only above the control) and as well the total n6 FA proportion, in a dose-dependent way. In contrast, the SFL partial replacement significantly increased linoleic acid proportion in a dose-dependent manner, as well as that of PUFA and the total $\mathrm{n} 6$ proportions, in a similar way. The marked n6 FA addition failed to 
280 BELOVAI et al.: NEW APPLICATION OF LECITHIN AS FAT-REPLACER IN MEAT PRODUCTS

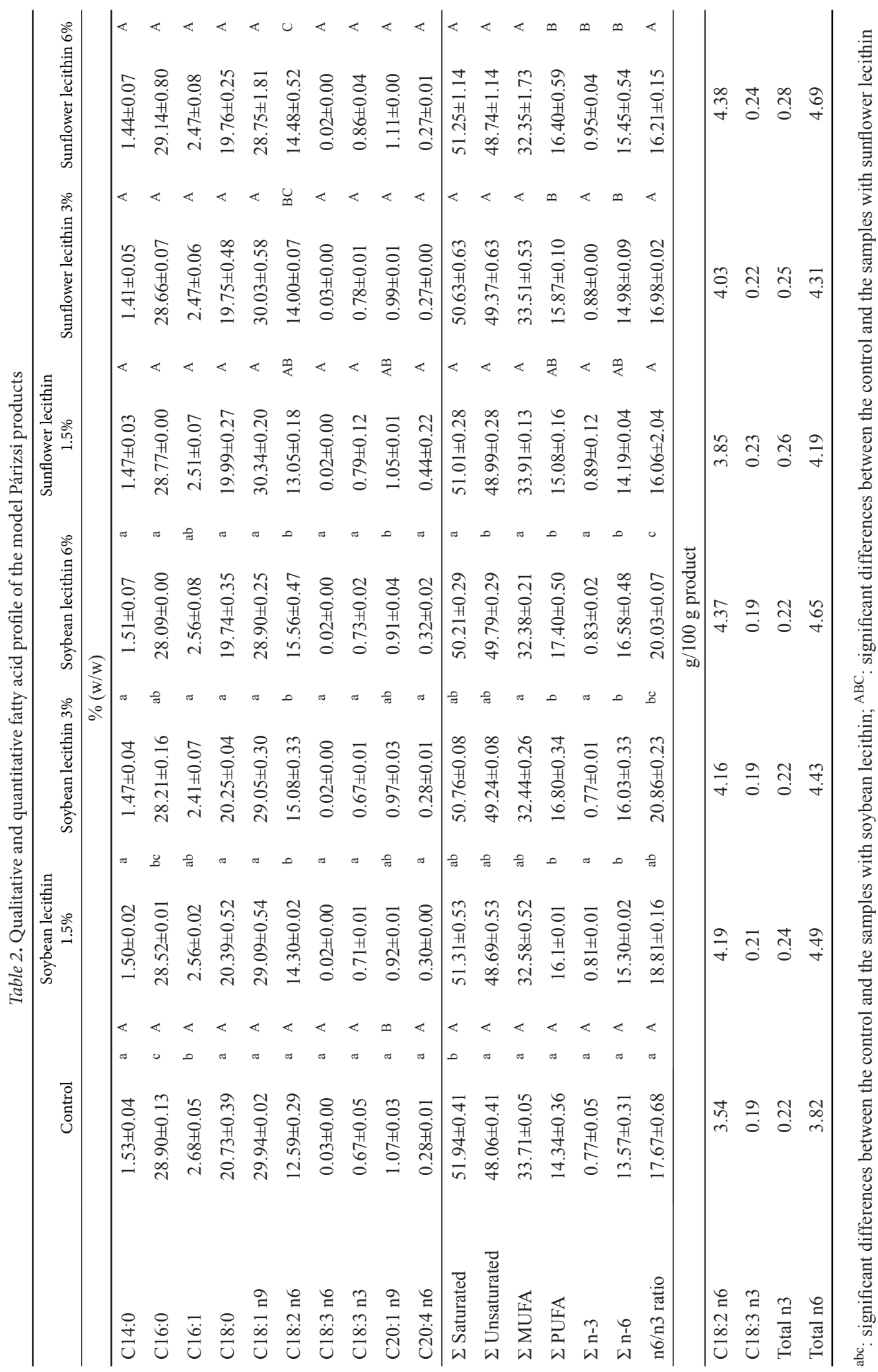


modify the $\mathrm{n} 6 / \mathrm{n} 3$ ratio of the product as meat and backfat were already rich in these FAs. Although the $\mathrm{n} 3$ fatty acid content in the $6 \%$ SFL replacement was slightly higher, and it seems there is a connection between the higher amount of sunflower lecithin and $\mathrm{n} 3$ fatty acid content, it could not be verified statistically. The lecithins are PUFA sources, effective emulsifiers and antioxidants (SARUDI et al., 2004). Since their very high PUFA content is primarily oxidized, they are protecting other food lipid fractions. Accordingly, it was found that the higher SFL or SBL substitution levels were matched with more intensive lipid peroxidation.

Significant differences were found in the colour between the control and the $3 \%$ and $6 \%$ substituted samples (Table 3): redness $\left(a^{*}\right)$ decreased in parallel with the increasing lecithin addition, while the yellow colour component $\left(\mathrm{b}^{*}\right)$ increased gradually. A $1.5 \%$ substitution of backfat with lecithin caused marked decrease in lightness, but by higher lecithin amounts the $L^{*}$ value of the control samples was approached.

Table 3. CIE Lab colour of the samples - substitution dependent changes

\begin{tabular}{lcccccc}
\hline Sample & \multicolumn{1}{c}{$\mathrm{L}$} & & \multicolumn{2}{c}{$\mathrm{a}^{*}$} & & \\
\hline Control & $76.17 \pm 0.18$ & $\mathrm{~b}$ & $17.32 \pm 0.25$ & $\mathrm{c}$ & $6.49 \pm 0.06$ & $\mathrm{ab}$ \\
Soybean lecithin 1.5\% & $75.01 \pm 0.55$ & $\mathrm{a}$ & $16.97 \pm 0.47$ & $\mathrm{bc}$ & $6.67 \pm 0.22$ & $\mathrm{ab}$ \\
Soybean lecithin 3\% & $75.82 \pm 0.62$ & $\mathrm{ab}$ & $16.67 \pm 0.48$ & $\mathrm{ab}$ & $7.13 \pm 0.19$ & $\mathrm{c}$ \\
Soybean lecithin 6\% & $76.06 \pm 0.45$ & $\mathrm{~b}$ & $15.38 \pm 0.37$ & $\mathrm{a}$ & $7.2 \pm 0.15$ & $\mathrm{c}$ \\
\hline Control & $76.83 \pm 0.18$ & $\mathrm{~b}$ & $16.98 \pm 0.17$ & $\mathrm{bc}$ & $6.34 \pm 0.1$ & $\mathrm{a}$ \\
Sunflower lecithin 1.5\% & $75.31 \pm 0.39$ & ab & $16.75 \pm 0.32$ & $\mathrm{~b}$ & $6.78 \pm 0.14$ & $\mathrm{~b}$ \\
Sunflower lecithin 3\% & $75.86 \pm 0.50$ & $\mathrm{ab}$ & $16.42 \pm 0.30$ & $\mathrm{ab}$ & $7.34 \pm 0.2$ & $\mathrm{c}$ \\
Sunflower lecithin 6\% & $76.11 \pm 0.90$ & $\mathrm{~b}$ & $15.48 \pm 0.34$ & $\mathrm{a}$ & $7.85 \pm 0.28$ & $\mathrm{~d}$ \\
\hline
\end{tabular}

abcd: significant difference $(\mathrm{P}<0.05)$ between the samples

Lipid peroxidation was the lowest in the control sample with the highest level of fatty acid saturation (Fig. 1). Both supplementations evoked a dose dependent increase of the malondialdehyde (MDA) concentration compared to the control. Although not on a statistically significant level, the MDA production in the SFL treatment tended to be lower, compared to the SBL. Although SBL and SFL addition obviously increased the lipid peroxidation (compared to the control), we suppose some free radical scavenging activity of linoleic acid in SFL. This is underpinned by the finding that due to its very high unsaturation, the extent of MDA formation tended to be lower compared to the SBL. In this process, the autooxidation of linoleic acid as well the enzyme mediated (animal lipoxigenases) oxidation may be of primary importance, placing SFL linoleic acid as the primary target of lipid peroxidation (St. ANGelo, 1992). 


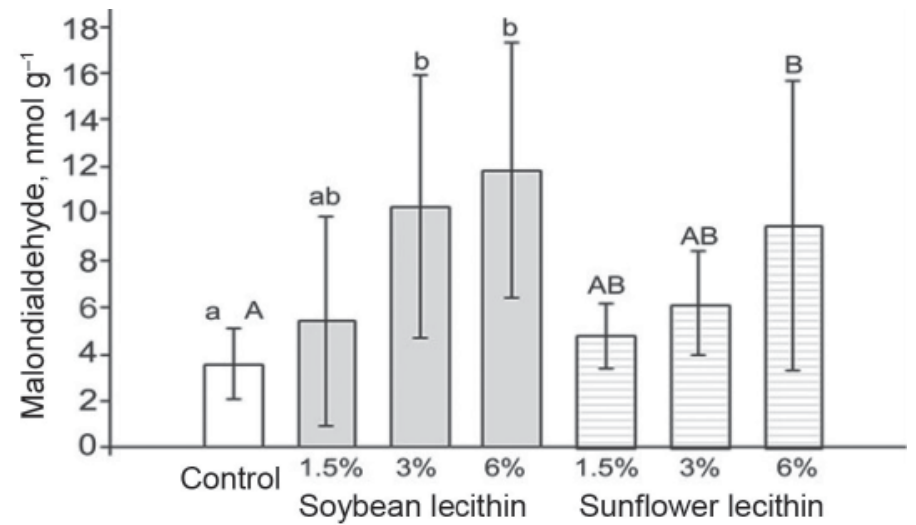

Fig. 1. The malondialdehyde concentration of fresh samples

In this case, the lecithin-substitution had an effect on sensory properties. In general, it was found that increasing lecithin addition decreased preference $(\mathrm{P}<0.001)$. After the elimination of two assessors, to reduce the assessors-effect, significant differences were found in saltiness $(\mathrm{P}<0.05)$, chewing resistance $(\mathrm{P}<0.001)$, and taste of meat dollop $(\mathrm{P}<0.05)$ (Fig. 2). Increasing lecithin addition increased the chewing resistance, the chewing fattiness sensing of the $1.5 \%$ SFL was the lowest $(\mathrm{P}<0.01)$ (Fig. 3). It is an evidence why it is used as an emulsifier in the food industry. SRINIVASSANE (2011) reported a disparate result, that oil addition to the bologna pork sausage did not change sensory attributes.

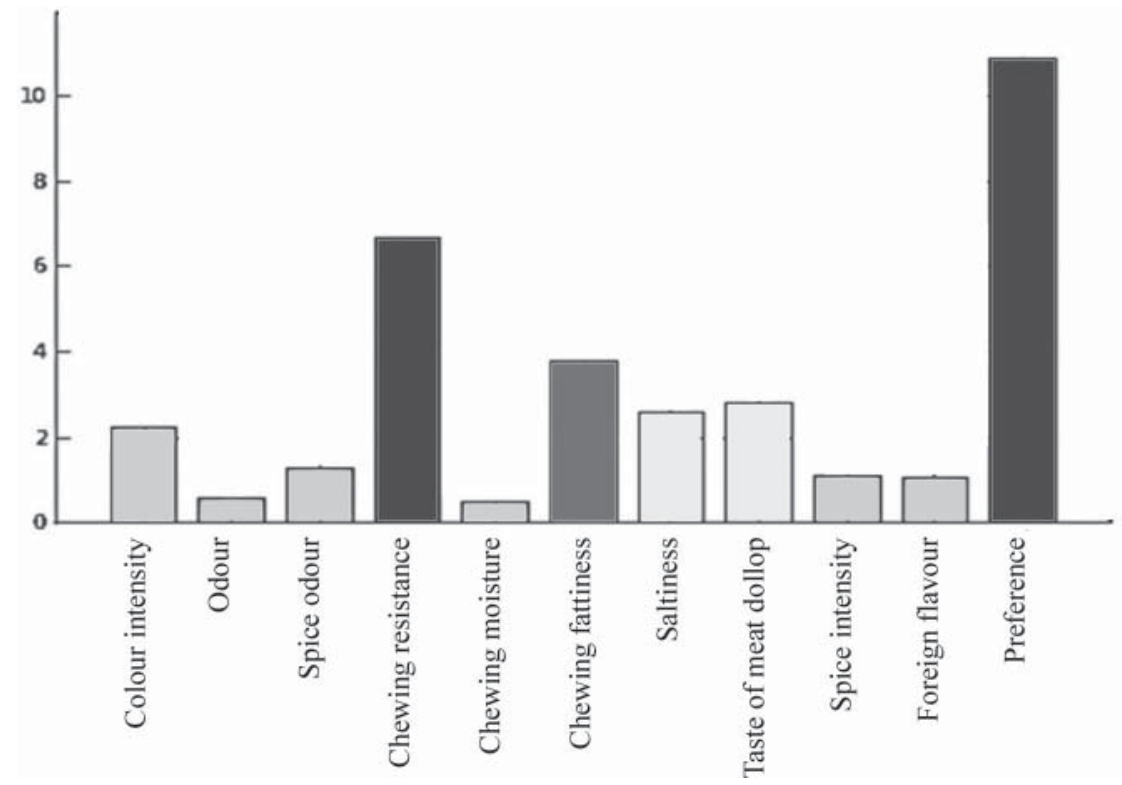

Fig. 2. Results of the sensory test. Significance: $\square$ : ns; $\square: \mathrm{P}<0.05 ; \square: \mathrm{P}<0.01 ; \square$ : $\mathrm{P}<0.001$ 


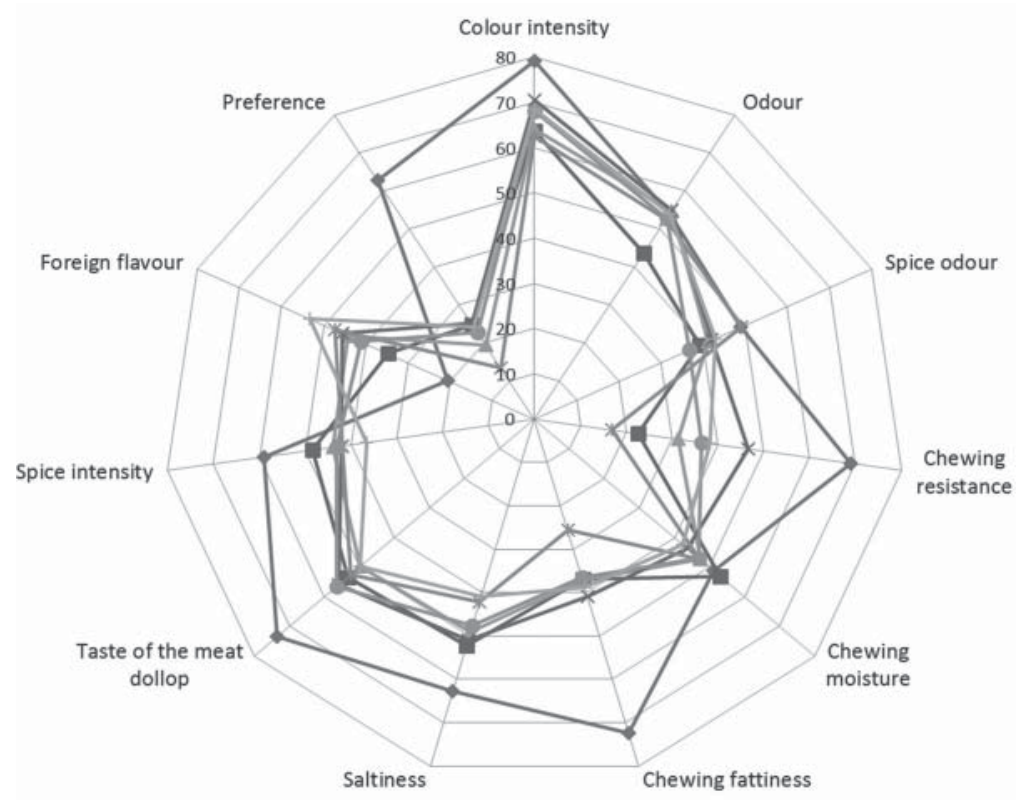

Fig. 3. Spider web diagram of sensory attributes based on the sensory test

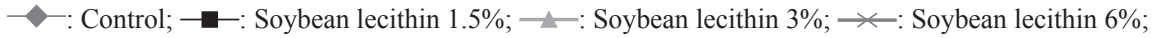
*

The EN results were tested for the effects of the applied supplements on the whole dataset, which resulted a classification value of $87.2 \%$ (CV: $84.2 \%$ ). Accordingly, it can be stated that the aromatic difference of SFL and SBL is perceptible by means of EN measurement. When the classification was performed separately on the applied supplementation levels (1.5, 3 , and $6 \%$ ), the higher level of lecithin was associated with the higher discrimination power ( 1.5 vs. $6 \%, 87.2$ vs. $98 \%)$. On the other hand, the classification ability of samples supplemented by SFL is higher than that of SBL. Analysing the 6\% supplementation level, the discrimination results were 100 and $96 \%$ (CV: 84.6 and 76\%) for SFL and SBL, respectively. The samples (1.5 and 6\%) were classified in case of both lecithin types (Figs 4 and 5) according to the first and second discriminant function. The $94.1 \%$ discrimination value is a promising result in terms of EN technology. However, the decisive parts of the misclassified samples during cross-validation (70.6\%) belong to the group of $1.5,3$, and $6 \%$, drawing the attention to the limitation of the sensory method applied. 


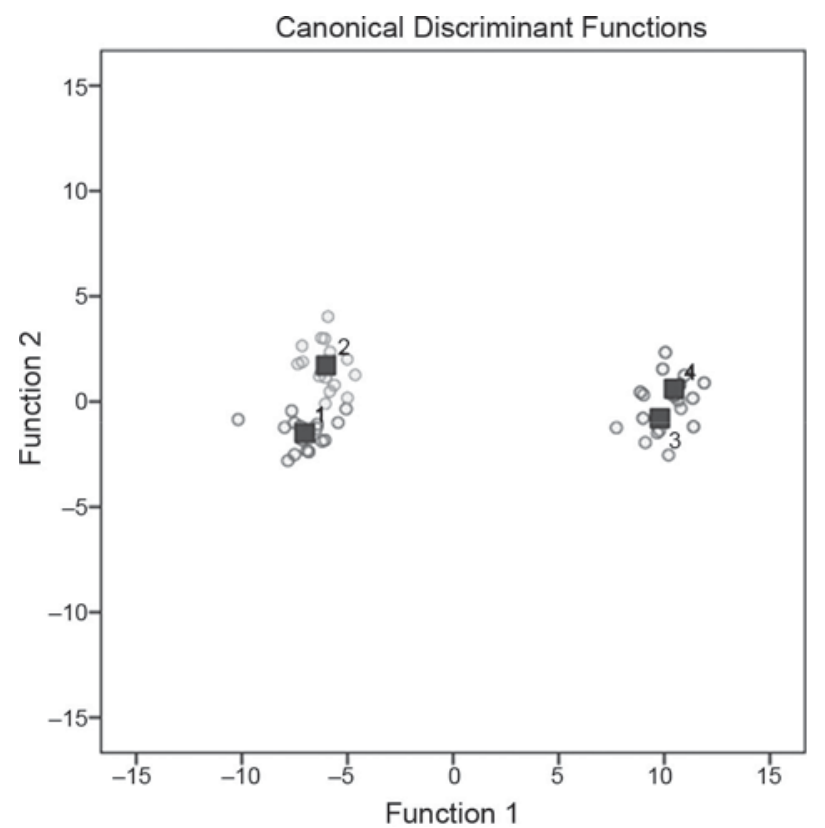

Fig. 4. Results of discriminant analysis in case of soybean supplementation $\mathrm{O}_{1}$ : Control; $\bigcirc_{2}$ : Soybean lecithin 1.5\%; O3: Soybean lecithin 3\%; $\bigcirc_{4}$ : Soybean lecithin 6\%; 口: Group centroid

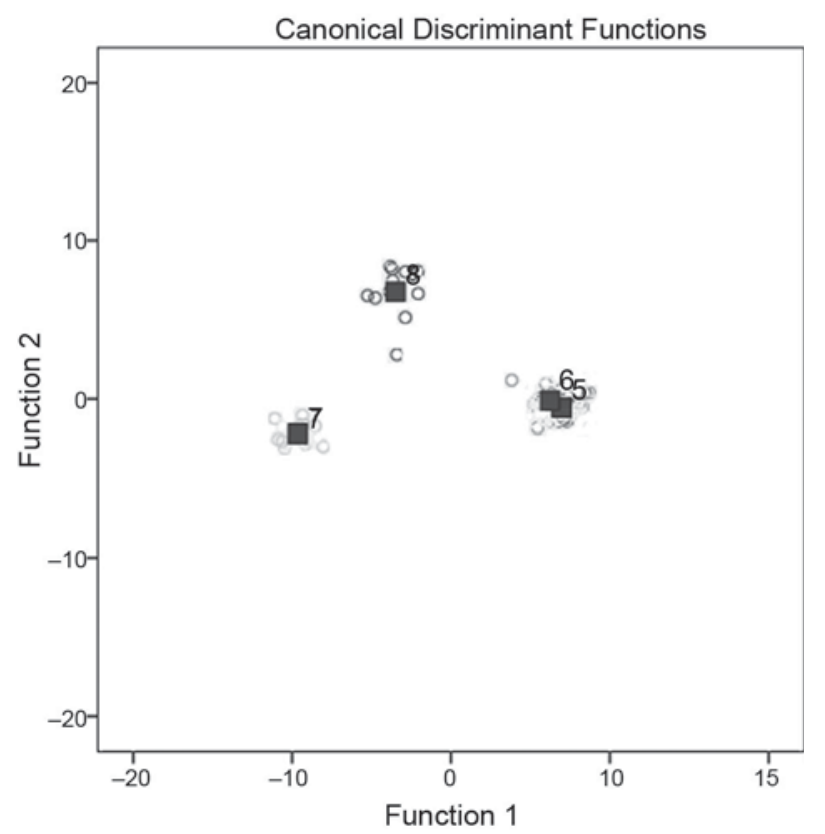

Fig. 5. Results of discriminant analysis in case of sunflower supplementation

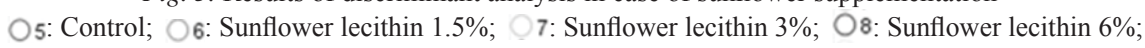
口: Group centroid 


\section{Conclusions}

The food industry already uses the lecithin as an emulsifier in chocolate, margarine, etc. without limitation during the manufacturing process, but the content must be indicated on the label. Our products are new possibilities to apply lecithin also in the meat industry to partly substitute the animal fat with more valuable plant lipids. Based on our results, $100 \mathrm{~g}$ Párizsi with $6 \%$ sunflower lecithin may cover $28 \%$ of Dietary Reference Intakes from linoleic acid (IOM, 2005). On the other hand, the fat-replacement can have an unfavourable influence on product quality. Further work focuses on the elimination of disturbing conditions raised by these natural additives, maintaining the advantageous colour and taste characteristics. According to the results and the literature, the EN technology could be applicable in evaluating the aromatic character of meat products supplemented with functional components.

The study was partly supported by the Bolyai Research Grant (BO/26/11/4) to A.Sz. and by TÁMOP 4.2.2. A projects.

\section{References}

Belovai, J., Romvári, R, Fébel, H., Szabó, A. \& BÁnÁti, D. (2014): Effects of n-3 fatty acid enrichment on the quality characteristics of a special Hungarian cold cut (Párizsi). Acta Alimentaria, 43, 604-613.

Christie, W.W. \& HAN, X. (2010): Lipid analysis - Isolation, separation, identification and lipidomic analysis. The Oily Press Lipid Library. London, U.K. 448 pages.

Cohn, J., Kamili, A., Wat, E., Chung, R.W. \& Tandy, S. (2010): Dietary phospholipids and intestinal cholesterol absorption. Nutrients, 2(2), 116-127.

Folch, J.M., Leeas, M. \& Sloance-Stanley, G.H. (1957): A simple method for the isolation and purification of total lipids from animal tissues. J. Biol. Chem., 226, 495-509.

IOM (2005): Dietary reference intakes for energy, carbohydrate. fiber, fat, fatty acids, cholesterol, protein, and amino acids (2002/2005). http://www.iom.edu/Global/News\%20Announcements/ /media/ C5CD2DD7840544979A549EC47E56A02B.ashx (last accessed: 24th May 2015)

Küllenberg, D., Taylor, L.A., Schneider, M. \& Massing, U. (2012): Health effects of dietary phospholipids. Lipids Health Dis., 11, 3.

Oкe, M., Jacob, J.K. \& Paliyath, G. (2010): Effect of soy lecithin in enhancing fruit juice/sauce quality. Food Res. Int., 43, 232-240.

Pearson, A.M. \& Gillett, T.A. (1999): Effects of fat on flavor in processed meats. -in: Processed meats. $3^{\text {rd }}$ ed., Aspen Publisher, Inc. Gaithersburg, pp. 356-358.

Placer, Z.A., Cushman, L.L. \& Johnson, B.C. (1966): Estimation of product of lipid peroxidation (malonyl dialdehyde) in biochemical systems. Anal. Biochem., 16, 359-364.

Rossi, M. (2007): Use of lecithin and lecithin fractions. -in: Huopalahti, R., López-Fandiño, R., Anton, M. \& Schade, R. (Eds) Bioactive egg compounds. Springer Publication, Berlin, Heidelberg. pp. 229-238.

Sarudi, I., Nagy, I., Szabó, A., Csapó-Kiss, Zs. \& Csordás, E. (2004): A nyers szójalecitin antioxidáns kapacitása (The total antioxidant capacity of raw soybean lecithin). Élelmiszervizsgálati Közlemények, 1, 13-19.

Schneider, M. \& Virmani, K. (2001): Phospholipids. -in: Young, J. (Ed.) Guide to functional food ingredients, Leatherhead Publishing, England, pp. 276-291.

SRinivassane, S. (2011): Development and evaluation of omega-3 fatty acids enriched chicken frankfurters. PhD dissertation, Dalhousie University, Halifax, pp. 1-182.

St. Angelo, A.J. (Ed.) (1992) Lipid oxidation in food. American Chemical Society, pp. 161-182.

Tokusoglu, Ö. \& ÜNAL, M.K. (2002): Fat replacers in meat products. Pak. J. Nutr., 2(3), 196-203. 